\title{
RESPONSE OF SOME WHEAT VARIETIES TO NITROGEN FERTILIZATION
}

Atia, R. H.* and Kh. E. Ragab**

* Soils, Water and Environment Res. Inst., Agric. Res. Center, Egypt.

${ }^{* *}$ Field crop Res. Inst. Wheat Res. Dep. Agric. Res. Center, Egypt.

\begin{abstract}
Two field experiments were conducted at Sakha Agricultural Research Station Farm, Kafr El-Sheikh Governorate, Egypt ( $31^{\circ} 05^{\prime} \mathrm{N}$ latitude and $30^{\circ} 56^{\prime} \mathrm{E}$ longitude) during 2009/2010\&2010/2011 winter seasons to investigate the response of some wheat varieties to different $\mathrm{N}$ levels. Split plot design with four replicates was applied, the main plots were assigned to four wheat varieties, Gimiza 9, Giza 168, Sakha 61 and Sakha 93. The subplots were assigned to four nitrogen levels of $0,30,60$ and 90 $\mathrm{kg} \mathrm{N} /$ fed. (fed. = 0.42 ha.).

The obtained results can be summarized as follows:

1-Wheat varieties significantly differed in grain, straw and biological yields, as well as harvest index, $\mathrm{N} \%, \mathrm{~N}$ uptake and protein content in the two seasons.

2-Gimiza 9 variety had the highest mean value of grain, straw and biological yields, and $\mathrm{N}$ uptake and protein content of grain and straw.

3-The grain, straw, biological yields, $\mathrm{N}$ uptake and protein content were significantly increased by increasing $\mathrm{N}$ levels.

4-The interaction between wheat varieties and $\mathrm{N}$ levels showed that Gimiza 9 variety had the highest value of grain yield $(2822.0 \mathrm{~kg} / \mathrm{fed})$ followed by, Giza $168(2681.0$ $\mathrm{kg} / \mathrm{fed}$.), Sakha 93 (2552.0 kg/fed.), and Sakha 61 (2475.0 kg/fed.), with $\mathrm{N}_{90}$ level.

5- The highest $\mathrm{N}$ uptake and protein content of grain and straw were obtained by Gimiza 9 with $\mathrm{N}_{90}$ level and the lowest value by Sakha 93 under $\mathrm{N}_{0}$ level .

6-Gimiza 9 had the highest net return value of 8663.75 L.E./fed. followed by Giza 168 (7776.55 L.E./fed)., Sakha 93 (7057.05 L.E./fed.) and Sakha 61 (6769.15 L.E./fed.) with $\mathrm{N}_{90}$ level.

7-The values of net return of fertilizer had the following order : Giza $168>$ Sakha $93>$
\end{abstract} Gimiza 9 > Sakha 61

Keywords: Wheat varieties, $\mathrm{N}$ levels, grain yield, $\mathrm{N}$ uptake, protein content and net return

\section{INTRODUCTION}

Wheat (Triticum aestivum, L.) is one of the most important major cereal crop allover the world as well as in Egypt. It is used as staple food for more than one third of the world population (Abd Allah and El-Gammaal, 2009). It is consumed in many forms such as bread, cakes, biscuits, bakery products, and many confectionery products. Its straw is used as animal feed and also for manufacturing paper. In Egypt the quantity of wheat grain production must be increased to cover local consumption. The annual consumption of wheat in Egypt is about 18.9 million tons, while the annual local production is about 9 million tons. Efforts of scientists to minimize the gap between local production and consumption are directed towards two ways i,e. expanding the cultivated wheat area and increasing the wheat productivity from the land unit area by selecting the high yielding varieties and balanced fertilization.

Nitrogen plays a vital role in increasing the yield of the crop. Application of proper amount of nitrogen is considered key to obtain bumper crop of wheat. 
Nitrogen comprises $7 \%$ of total dry matter of plants and is a constituent of many fundamental cell components such as nucleic acids, amino acids, enzymes, and photosynthetic pigments High wheat yields require increases in $\mathrm{N}$ application and the excessive addition of this nutrient can contribute to watercourse pollution (Semenov et al., 2007). Therefore, the use of high $\mathrm{N}$ rates that allow expressing yield potential of existing varieties in the actual market require careful and efficient management of nutrient with the purpose of minimizing losses due to lixiviation during crop development, avoiding pollution of the underground water and its harmful effect on human health and environmental sustainability.

Results of many researchers that could be achieved in Egypt revealed that nitrogen fertilizer levels significantly affected most of plant growth trials, yield and its component. The optimum nitrogen fertilizer level for wheat vary widely in amounts and ranged between 70 to $120 \mathrm{~kg} \mathrm{~N} /$ fed. according to environmental conditions (Atta Allah and Mohammed, 2003; Tammam and Tawfils, 2004; Salem, 2005; Mowafy, 2008; Mansour and Bassiouny, 2009 and Knany, et al. 2011). Application of very high nitrogen rate can reduce grain yield by increasing lodging and disease incidence. Hadzic (1986) found that $\mathrm{N}$-rates of $90-150 \mathrm{~kg} \mathrm{~N} / \mathrm{ha}$ increase the grain yields, and the rate above150 kg N/ha caused the yield decrease due to lodging. Mashali et al. (2011) and Abedi et al. ( 2011) indicated that wheat grain yield respond to $\mathrm{N}$ levels up to $90 \mathrm{~kg} \mathrm{~N} / \mathrm{fed}$ and $240 \mathrm{~kg} \mathrm{~N} / \mathrm{ha}$.

The excessive use of nitrogen fertilizers represents the major cost of crop production. Therefore many investigators have given more attention to the quantitative expression of the response of crops to fertilizer application based on changes in cultural practices. This would then enable us to calculate the returns of fertilizer application on which is of economical importance. The expected yield when this optimum rate is applied and the obtainable yield at specified rate of fertilizer application can also be predicted. Thabet and Balba (1994), Hassanein and El-Shebiny (2000), Atia (2005), Atia et al.. (2009), Mashali et al. (2011) and Atia et al. (2012) calculate the net return of nitrogen applied to decrease the costs of added fertilizers at the minimum point.

Wheat is a major source of protein compared with other cereal crops and contributes more than 25 percent of the protein consumed in the human diet. The protein content in the wheat grain is dependent on genotype but it is also clearly influenced by environmental variables such as nitrogen application, water access and temperature during growth especially through the grain filling period (Daniel and Triboi, 2000)

The objectives of the present study were to evaluate the response of some wheat varieties to $\mathrm{N}$ level application, $\mathrm{N} \%, \mathrm{~N}$ uptake, protein content and calculate the net return of grain and straw yields.

\section{MATERIALS AND METHODS}

Two field experiments were conducted at Sakha Agricultural Research Station Farm, Kafr El-Sheikh Governorate, Egypt, $\left(31^{\circ} 05^{\prime} \mathrm{N}\right.$ latitude and $30^{\circ} 56^{\prime}$ E longitude) during two winter seasons of 2009/2010 \& 2010/2011 to 
study the yield of some wheat varieties as affected by nitrogen levels, $\mathrm{N}$ uptake and protein content and net return at Northern Delta region. Four wheat varieties were used, Gimiza 9, Giza 168, Sakha 61 and Sakha 93. The experimental soil was prepared by suitable plowing and land leveler. The recommended grains weight from each wheat variety $(60 \mathrm{~kg} / \mathrm{fed}$.) was sown by seed planter $20 \mathrm{~cm}$ between the lines on 25/11/2009 and 19/11/2010. Split plot design was used with four replicates. The plot area was $14 \mathrm{~m}^{2}$. The main plots were randomly assigned to the four wheat varieties and the sub plots were randomly assigned to four nitrogen levels of zero $\left(\mathrm{N}_{0}\right), 30,\left(\mathrm{~N}_{30}\right), 60$ $\left(\mathrm{N}_{60}\right)$ and $90 \mathrm{~kg} \mathrm{~N} / \mathrm{fed}$. ( $\left.\mathrm{N}_{90}\right)$, (fed..=0.42 ha..). Phosphorus fertilization was added at the rate of $15 \mathrm{~kg} \mathrm{P}_{2} \mathrm{O}_{5} / \mathrm{fed}$.in the form of super phosphate $15 \% \mathrm{P}_{2} \mathrm{O}_{5}$ during the soil preparation $\left(\mathrm{P}_{2} \mathrm{O}_{5}=2.29 \times \mathrm{P}\right)$. Potassium fertilization was added at the rate of $24 \mathrm{~kg} \mathrm{~K} \mathrm{~K}_{2} \mathrm{O} / \mathrm{fed}$. in one dose with the first irrigation in the form of potassium sulphate $48 \% \mathrm{~K}_{2} \mathrm{O}\left(\mathrm{K}_{2} \mathrm{O}=1.2 \times \mathrm{K}\right)$. Nitrogen fertilization was added at two equal doses with the first and second irrigations in the form of urea $46.5 \% \mathrm{~N}$. Composite soil sample was collected from the experimental soil before sowing, prepared to determine some soil properties according to Black et al. (1965). Some physical and chemical characteristics are presented in Table (1). Plant samples at harvest were wet digested using sulphuric and perchloric acids, total nitrogen was determined in the plant samples digestion by the microkjldahel method according to Jackson (1967). The return of wheat yields was calculated as follows:

Return of grain yield (L. E./fed. ) = Grain yield (kg/fed.) $\times 2.6$ ( L. E./kg)

Return of straw yield (L. E./fed.) = Straw yield (kg/fed.) $\times 0.4$ ( L. E./kg.)

The net return of fertilizer (L. E./fed.) $=$ Total return of (grain + straw yields) cost of fertilizer

Increase over control $=$. The net return of fertilizer - control.

Protein yield $(\mathrm{kg} / \mathrm{fed}$.) was calculated by multiplying $\mathrm{N}$ uptake by the factor of 5.7.

\section{Statistical analysis:}

Combined analysis was conducted for the data of the two growing seasons according to Cochran and Cox (1957). The differences between the mean values were compared by Duncan's Multiple Range Test (Duncan, 1955).

Table (1): Some physical and chemical properties of the experimental soils.

\begin{tabular}{|c|c|c|c|c|c|c|c|c|c|c|}
\hline \multirow[t]{2}{*}{ Seasons } & \multirow[t]{2}{*}{$\begin{array}{c}\text { Sand } \\
\%\end{array}$} & \multirow[t]{2}{*}{ Silt\% } & \multirow[t]{2}{*}{$\begin{array}{c}\text { Clay } \\
\%\end{array}$} & \multirow[t]{2}{*}{ Texture } & \multirow[t]{2}{*}{$\begin{array}{l}E C e^{\star} \\
\mathrm{dS} / \mathrm{m}\end{array}$} & \multirow[t]{2}{*}{$\mathrm{pH}^{\star \star}$} & \multirow[t]{2}{*}{$\underset{\%}{O}$} & \multicolumn{3}{|c|}{$\begin{array}{c}\text { Available } \\
\text { nutrients } \\
\mathrm{mg} / \mathrm{kg}\end{array}$} \\
\hline & & & & & & & & $\mathbf{N}$ & $\mathbf{P}$ & $K$ \\
\hline 2009/2010 & 18.8 & 22.5 & 58.7 & Clayey & 3.1 & 7.9 & 1.5 & 25 & 11 & 360 \\
\hline $2010 / 2011$ & 18.1 & 22.9 & 59.0 & Clayey & 2.8 & 8.0 & 1.6 & 28 & 10 & 350 \\
\hline
\end{tabular}

$\mathrm{ECe}^{*}$ in the soil paste extract

$\mathrm{pH}^{\star \star} 1: 2.5$ soil : water suspension 


\section{RESULTS AND DISCUSSION}

\section{1- Grain yield}

Data presented in Table 2 showed grain yield of wheat as affected by varieties and $\mathrm{N}$ levels. Data showed that wheat varieties were affected by grain yield significantly in the two seasons. Gimiza 9 variety had the highest mean value of grain yield (2471.0 kg/fed) followed by, Giza $168(2243.0$ $\mathrm{kg} / \mathrm{fed}$ ), Sakha 61 (2038.5 kg/fed), and Sakha 93 (1965.5 kg/fed). The mean value of Gimiza 9 was higher than Sakha 93 by $25.7 \%$. Results showed that Gimiza 9 had the highest grain value of $1564 \mathrm{~kg} / \mathrm{fed}$. with $\mathrm{N}_{0}$. These results may be due to Gimiza 9 variety can utilize soil nitrogen more than the other three varieties. With regard to $\Delta \%$ values, Giza 168 had the highest value of $128 \%$ and Gimiza 9 had the lowest one of $80.4 \%$ with $\mathrm{N}_{90}$. Data showed that grain yield was significantly increased by increasing nitrogen levels. On average of the varieties the mean values of grain yield increased from 1284.8 $\mathrm{kg} / \mathrm{fed}$. to $2250.5,2550.3$ and $2632.5 \mathrm{~kg} / \mathrm{fed}$. as nitrogen levels increased from $N_{0}$ to $N_{30}, N_{60}$, and $N_{90}$, respectively. With regard to $\Delta \%$ values, increasing $\mathrm{N}$ levels from $\mathrm{N}_{0}$ to $\mathrm{N}_{30}$ increased grain yield by $75.2 \%$ while it was only increased by $25.5 \%$ and $6.7 \%$ when $\mathrm{N}$ level increased to $\mathrm{N}_{60}$, and $\mathrm{N}_{90}$ respectively, showing that yield increase declined by increasing $\mathrm{N}$ level. Many investigators such as Hassanein and El-Shebiny (2000), Mashali et al. (2011) and Atia et al. (2012) stated that the highest increase of yield and highest efficiency of nitrogen fertilizer was at the first dose and decreased as $\mathrm{N}$ levels increased. These results are in agreement with those reported by El-Zaher and Salem (2005), Abdelgader et al. (2010) and Knany et al. (2011). The interaction between wheat varieties and $\mathrm{N}$ level showed highly significant effect on grain yield. Data in Table 2 showed that the highest grain yield value of $2822.0 \mathrm{~kg} / \mathrm{fed}$. was obtained with Gimiza 9 and $\mathrm{N}_{90}$ level followed by Giza $168(2681.0 \mathrm{~kg} / \mathrm{fed})$, Sakha 93 (2552.0 kg/fed.), and Sakha 61 (2475.0 $\mathrm{kg} / \mathrm{fed}$ ), with the same $\mathrm{N}$ level, respectively. On contrast the lowest value of $1123.0 \mathrm{~kg}$ fed. ${ }^{-1}$ was recorded with Sakha 93 and $\mathrm{N}_{0}$ level. These results were in agreement with those obtained by Mashali et al. (2011) who indicated that wheat grain yield respond to $\mathrm{N}$ levels up to $90 \mathrm{kgN} / \mathrm{fed}$. and the contribution of $\mathrm{N}$ fertilizer in yield production increased when $\mathrm{N}$ levels increased.

Table 2: Wheat grain yield as affected by varieties and $\mathrm{N}$ levels (mean of two seasons 2009/10\&2010/11).

\begin{tabular}{|c|c|c|c|c|c|c|c|c|c|c|}
\hline \multirow[b]{2}{*}{ Treatments } & \multicolumn{2}{|c|}{ Gimiza 9} & \multicolumn{2}{|c|}{ Giza 168} & \multicolumn{2}{|c|}{ Sakha 61} & \multicolumn{2}{|c|}{ Sakha 93} & \multicolumn{2}{|c|}{ Mean } \\
\hline & $\begin{array}{c}\text { Grain } \\
\text { yield } \\
\text { kg/fed. }\end{array}$ & $\Delta \%$ & $\begin{array}{c}\text { Grain } \\
\text { yield } \\
\text { kg/fed. }\end{array}$ & $\Delta \%$ & $\begin{array}{c}\text { Grain } \\
\text { yield } \\
\text { kg/fed. }\end{array}$ & $\Delta \%$ & $\begin{array}{c}\text { Grain } \\
\text { yield } \\
\text { kg/fed. }\end{array}$ & $\Delta \%$ & $\begin{array}{c}\text { Grain } \\
\text { yield } \\
\text { kg/fed. }\end{array}$ & $\Delta \%$ \\
\hline $\mathrm{N}_{0}$ & $1564.0 \mathrm{c}$ & 0.0 & $1176.0 \mathrm{c}$ & 0.0 & $1276.0 \mathrm{~d}$ & 0.0 & $1123.0 \mathrm{c}$ & 0.0 & $1284.8 \mathrm{~d}$ & 0.0 \\
\hline $\mathrm{N}_{30}$ & $2699.0 \mathrm{~b}$ & 72.6 & $2493.0 \mathrm{~b}$ & 112.0 & $2087.0 \mathrm{c}$ & 63.6 & $1723.0 \mathrm{~b}$ & 53.4 & $2250.5 \mathrm{c}$ & 75.2 \\
\hline $\mathrm{N}_{60}$ & $2799.0 \mathrm{a}$ & 79.0 & $2622.0 \mathrm{a}$ & 123.0 & $2316.0 \mathrm{~b}$ & 81.5 & $2464.0 \mathrm{a}$ & 119.4 & $2550.3 \mathrm{~b}$ & 100.7 \\
\hline $\mathrm{N}_{90}$ & $2822.0 \mathrm{a}$ & 80.4 & $2681.0 \mathrm{a}$ & 128.0 & $2475.0 \mathrm{a}$ & 94.0 & $2552.0 \mathrm{a}$ & 127.2 & $2632.5 \mathrm{a}$ & 107.4 \\
\hline mean & 2471.0 & 58.0 & 2243.0 & 90.7 & 2038.5 & 59.8 & 1965.5 & 75.0 & & 70.9 \\
\hline \multicolumn{11}{|c|}{ LSD (0.05) $\quad$ LSD (0.01) } \\
\hline $\begin{array}{l}\mathrm{N} \text { levels } \\
\text { varieties }\end{array}$ & & $\begin{array}{r}86.6 \\
88 .\end{array}$ & & 1 & & & & & & \\
\hline
\end{tabular}




\section{2- Straw yield}

Results in Table (3) illustrated wheat straw yield as affected by of varieties and nitrogen levels. All varieties differed significantly in the straw yield, where Gimiza 9 had the greatest mean value than the three other varieties. Gimiza 9 was superior to the rest of the studied genotypes, where it had the highest mean value of $5963.5 \mathrm{~kg} / \mathrm{fed}$.. On contrast Sakha 93 had the lowest mean value of $(4512.8 \mathrm{~kg} / \mathrm{fed}$.). The values of straw yield increased significantly as nitrogen levels increased. It increased from $4121.8 \mathrm{~kg} / \mathrm{fed}$. to $5087.5,5458.0$ and $5794.5 \mathrm{~kg} / \mathrm{fed}$. as nitrogen levels increased from $\mathrm{N}_{0}$ to $\mathrm{N}_{30}, \mathrm{~N}_{60}$, and $\mathrm{N}_{90}$ respectively. The values of $\Delta \%$ had the same trend of grains, where it increased as $\mathrm{N}$ levels increased. The interactions between varieties and $\mathrm{N}$ levels in Table 3 showed that the highest straw yield value $(6885.0 \mathrm{~kg} / \mathrm{fed}$.) of Gimiza 9 was obtained at $N_{90}$ level and the minimum value of $3634.0 \mathrm{~kg} / \mathrm{fed}$. was obtained by Giza 168 with no fertilizer addition. Similar results were obtained by Mattas et al. (2011) who reported that increasing levels of nitrogen from 120 to 150 and to $180 \mathrm{~kg} / \mathrm{ha}$. significantly increased wheat grain and straw yields.

Table 3: Wheat straw yield as affected by varieties and $\mathrm{N}$ levels (mean of two seasons 2009/10\&2010/11).

\begin{tabular}{|c|c|c|c|c|c|c|c|c|c|c|}
\hline \multirow[b]{2}{*}{$\begin{array}{c}\text { Treatment } \\
\text { s }\end{array}$} & \multicolumn{2}{|c|}{ Gimiza 9} & \multicolumn{2}{|c|}{ Giza 168} & \multicolumn{2}{|c|}{ Sakha 61} & \multicolumn{2}{|c|}{ Sakha 93} & \multicolumn{2}{|c|}{ Mean } \\
\hline & $\begin{array}{c}\text { Straw } \\
\text { yield } \\
\text { kg/fed. }\end{array}$ & $\Delta \%$ & $\begin{array}{c}\text { Straw } \\
\text { yield } \\
\text { kg/fed. }\end{array}$ & $\Delta \%$ & $\begin{array}{c}\text { Straw } \\
\text { yield } \\
\text { kg/fed. }\end{array}$ & $\Delta \%$ & $\begin{array}{c}\text { Straw } \\
\text { yield } \\
\text { kg/fed. }\end{array}$ & $\Delta \%$ & $\begin{array}{c}\text { Straw } \\
\text { yield } \\
\text { kg/fed. }\end{array}$ & $\Delta \%$ \\
\hline $\mathrm{N}_{0}$ & $4763.0 \mathrm{~d}$ & 0.0 & $3634.0 \mathrm{~d}$ & 0.0 & $4392.0 \mathrm{c}$ & 0.0 & $3698.0 \mathrm{~d}$ & 0.0 & 4121.8 & 0.0 \\
\hline $\mathrm{N}_{30}$ & $5815.0 \mathrm{c}$ & 22.1 & $5551.0 \mathrm{c}$ & 52.8 & $4827.0 \mathrm{~b}$ & 9.9 & $4157.0 \mathrm{c}$ & 12.4 & 5087.5 & 23.4 \\
\hline $\mathrm{N}_{60}$ & $6391.0 \mathrm{~b}$ & 34.2 & $5745.0 \mathrm{~b}$ & 58.1 & $4939.0 \mathrm{a}$ & 12.5 & $4757.0 \mathrm{~b}$ & 28.6 & 5458.0 & 32.4 \\
\hline $\mathrm{N}_{90}$ & $6885.0 \mathrm{a}$ & 44.6 & $5980.0 \mathrm{a}$ & 64.5 & $4874.0 \mathrm{ab}$ & 11.0 & $5439.0 \mathrm{a}$ & 47.1 & 5794.5 & 40.6 \\
\hline mean & 5963.5 & 25.2 & 5227.5 & 43.8 & 4758.0 & 8.3 & 4512.8 & 22.0 & 5115.4 & 24.8 \\
\hline $\begin{array}{l}\text { LSD (0.05) } \\
\text { N levels } \\
\text { varieties }\end{array}$ & & $\begin{array}{r}\text { D }(0.0 \\
78.3 \\
86.3\end{array}$ & & & $\begin{array}{l}07.09 \\
16.99\end{array}$ & & & & & \\
\hline
\end{tabular}

\section{3- Biological yield}

As shown in Table 4 the wheat varieties and nitrogen levels influenced biological yield significantly. Data showed that there were highly significant differences among varieties. The mean values of varieties can be arranged as the following order: Gimiza $9>$ Giza $128>$ Sakha $61>$ Sakha 93. The mean value of Gimiza 9 was the highest $(8434.5 \mathrm{~kg} / \mathrm{fed}$..) and the mean value of Sakha $93(6478.3 \mathrm{~kg} / \mathrm{fed}$.) was the lowest. With regard to the mean of $\Delta \%$ values, Giza 168 had the highest value of $55.3 \%$ and Saka 61 had the lowest one of $19.9 \%$. On contrast Giza 168 utilized from fertilizer more than others. These results were in agreement with those reported by El-Zaher and Salem (2005) and Abedi et al. ( 2011). Results clearly indicate that the biological yield was significantly increased as $\mathrm{N}$ levels increased up to $\mathrm{N}_{90}$ in the two seasons. The values of increases were $36.4,49.2$, and $57.2 \%$ as $\mathrm{N}$ levels increased from $N_{0}$ to $N_{30}, N_{60}$, and $N_{90}$, respectively. The interaction between varieties and N-levels showed that the highest biological yield value of Gimiza 9 (9707 kg/fed.) followed by Giza 168 ( 8661.0 kg/fed.), (Sakh 93 (7991.0 
$\mathrm{kg} / \mathrm{fed}$.) and Sakha 61 (7349.0 kg/fed.) at $\mathrm{N}_{90}$. The lowest one was (4810.0 $\mathrm{kg} / \mathrm{fed}$.) with Giza 168 and $\mathrm{N}_{0}$.

Table 4: Wheat biological yield as affected by varieties and $\mathrm{N}$ levels (mean of two seasons 2009/10\&2010/11).

\begin{tabular}{|c|c|c|c|c|c|c|c|c|c|c|}
\hline \multirow[b]{2}{*}{$\begin{array}{c}\text { Treatment } \\
\text { s }\end{array}$} & \multicolumn{2}{|c|}{ Gimiza 9} & \multicolumn{2}{|c|}{ Giza 168} & \multicolumn{2}{|c|}{ Sakha 61} & \multicolumn{2}{|c|}{ Sakha 93} & \multicolumn{2}{|c|}{ Mean } \\
\hline & \begin{tabular}{|c|} 
Biological \\
yield \\
kg/fed..
\end{tabular} & $\Delta \%$ & $\begin{array}{c}\text { Biologica } \\
\text { I yield } \\
\text { kg/fed. }\end{array}$ & $\Delta \%$ & \begin{tabular}{|l|} 
Biologic \\
al yield \\
$\mathrm{kg} / \mathrm{fed}$.
\end{tabular} & $\Delta \%$ & $\begin{array}{c}\text { Biologica } \\
\text { I yield } \\
\text { kg/fed. }\end{array}$ & $\Delta \%$ & \begin{tabular}{|l|} 
Biologic \\
al yield \\
$\mathrm{kg} / \mathrm{fed}$.
\end{tabular} & $\Delta \%$ \\
\hline $\mathrm{N}_{0}$ & $6327.0 \mathrm{~d}$ & 0.0 & $4810.0 \mathrm{~d}$ & 0.0 & $5668.0 \mathrm{~d}$ & 0.0 & $4821.0 \mathrm{~d}$ & 0.0 & 5406.5 & 0.0 \\
\hline $\mathrm{N}_{30}$ & $8514.0 \mathrm{c}$ & 34.6 & $8044.0 \mathrm{c}$ & 67.2 & $6914.0 \mathrm{c}$ & 22.0 & $5880.0 \mathrm{c}$ & 22.0 & 7338.0 & 36.4 \\
\hline $\mathrm{N}_{60}$ & $9190.0 \mathrm{~b}$ & 45.3 & $8367.0 \mathrm{~b}$ & 74.0 & $7255.0 \mathrm{~b}$ & 28.0 & $7221.0 \mathrm{~b}$ & 49.8 & 8008.3 & 49.2 \\
\hline $\mathrm{N}_{90}$ & $9707.0 \mathrm{a}$ & 53.4 & $8661.0 \mathrm{a}$ & 80.1 & $7349.0 \mathrm{a}$ & 29.7 & $7991.0 \mathrm{a}$ & 65.8 & 8427.0 & 57.2 \\
\hline mean & 8434.5 & 33.3 & 7470.5 & 55.3 & 6796.5 & 19.9 & 6478.3 & 34.4 & 7294.9 & 35.7 \\
\hline \multicolumn{11}{|c|}{ LSD (0.05) LSD (0.01) } \\
\hline \multicolumn{11}{|c|}{$\mathrm{N}$ levels $\quad 63.8$} \\
\hline
\end{tabular}

\section{4- Harvest index}

Data in Table 5 showed the harvest index of wheat as affected by varieties and $\mathrm{N}$ levels, where the effects were significant on average of the two seasons. Data showed that the mean values of harvest index arranged as following: Sakha $93>$ Sakha $61>$ Giza $168>$ Gimiza 9. On the other hand the effect of $\mathrm{N}$ levels was highly significant on harvest index. The mean value of harvest index increased from 0.237 to $0.305,0.320$ and 0.314 as $\mathrm{N}$ levels increased from $\mathrm{N}_{0}$ to $\mathrm{N}_{30}, \mathrm{~N}_{60}$, and $\mathrm{N}_{90}$, respectively. The interaction values showed that Sakha 61 variety had the highest value of 0.337 with $N_{90}$ and the lowest one of 0.225 . with $\mathrm{N}_{0}$. Mattas et al. (2011) stated that the increase in nitrogen level from 120 to 150 and to $180 \mathrm{~kg} \mathrm{ha}^{-1}$ resulted in significant increase in harvest index .

Table 5:Harvest index of wheat as affected by varieties and $\mathrm{N}$ levels (mean of two seasons 2009/10\&2010/11).

\begin{tabular}{|c|c|c|c|c|c|}
\hline Treatments & Gimiza 9 & Giza 168 & Sakha 61 & Sakha 93 & Mean \\
\hline $\mathrm{N}_{0}$ & $0.247 \mathrm{~d}$ & $0.244 \mathrm{~b}$ & $0.225 \mathrm{~d}$ & $0.233 \mathrm{~d}$ & 0.237 \\
$\mathrm{~N}_{30}$ & $0.317 \mathrm{a}$ & $0.310 \mathrm{a}$ & $0.302 \mathrm{c}$ & $0.293 \mathrm{c}$ & 0.305 \\
$\mathrm{~N}_{60}$ & $0.305 \mathrm{~b}$ & $0.313 \mathrm{a}$ & $0.319 \mathrm{~b}$ & $0.341 \mathrm{a}$ & 0.320 \\
$\mathrm{~N}_{90}$ & $0.291 \mathrm{C}$ & $0.310 \mathrm{a}$ & $0.337 \mathrm{a}$ & $0.319 \mathrm{~b}$ & 0.314 \\
\hline mean & 0.290 & 0.294 & 0.296 & 0.297 & 0.294 \\
\hline LSD (0.05) & LSD (0.01) & & \\
$\mathrm{N}$ levels & $\mathbf{0 . 0 0 6 2}$ & $\mathbf{0 . 0 0 8 7}$ & & \\
varieties & $\mathbf{0 . 0 0 5 4}$ & $\mathbf{0 . 0 0 7 3}$
\end{tabular}

\section{5- Nitrogen percentage in grain and straw ( $\mathrm{N} \%)$}

Data in Table 7 showed that $\mathrm{N} \%$ in grain and straw of wheat varieties differed significantly in the two seasons. The values of $\mathrm{N} \%$ in grain and straw significantly increased as $\mathrm{N} \%$ levels increased, where the mean value of $\mathrm{N} \%$ in grain increased from $1.23 \%$. to $1.59,1.66$ and $1.68 \%$ as $\mathrm{N}$ levels increased from $\mathrm{N}_{0}$ to $\mathrm{N}_{30}, \mathrm{~N}_{60}$ and $\mathrm{N}_{90}$ respectively. The values of $\mathrm{N} \%$ in straw had the same trend. The interaction values showed that the highest value of grain $\mathrm{N} \%$ was $(1.68 \%)$ and the lowest one was $1.2 \%$. On the other 
hand that the highest value of $\mathrm{N} \%$ in straw was $(0.75 \%)$ and the lowest one was $0.47 \%$.

Table 6: $\mathbf{N} \%$ in grain and straw as affected by varieties and $\mathrm{N}$ levels (mean of two seasons 2009/10\&2010/11).

\begin{tabular}{|c|c|c|c|c|c|c|c|c|c|c|}
\hline & \multicolumn{5}{|c|}{$\mathrm{N} \%$ in grain } & \multicolumn{5}{|c|}{$\mathrm{N} \%$ in straw } \\
\hline & $\begin{array}{c}\text { Gimiz } \\
9 \\
\end{array}$ & $\begin{array}{c}\text { Giza } \\
168 \\
\end{array}$ & \begin{tabular}{|c} 
Sakha \\
61
\end{tabular} & \begin{tabular}{|c|} 
Sakha \\
93 \\
\end{tabular} & mean & $\begin{array}{c}\text { Gimiza } \\
9\end{array}$ & \begin{tabular}{|c|} 
Giza \\
168 \\
\end{tabular} & $\begin{array}{c}\text { Sakha } \\
61\end{array}$ & $\begin{array}{c}\text { Sakha } \\
93\end{array}$ & mean \\
\hline $\mathrm{N}_{0}$ & $1.20 \mathrm{c}$ & $1.26 \mathrm{~b}$ & $1.20 \mathrm{~b}$ & $1.26 \mathrm{c}$ & 1.23 & $0.54 \mathrm{~b}$ & $0.57 \mathrm{~b}$ & $0.47 \mathrm{~b}$ & $0.54 \mathrm{~b}$ & 0.53 \\
\hline $\mathrm{N}_{30}$ & $1.61 \mathrm{~b}$ & $1.68 \mathrm{a}$ & $1.68 \mathrm{a}$ & $1.40 \mathrm{~b}$ & 1.59 & $0.69 a$ & $0.71 \mathrm{a}$ & $0.58 \mathrm{a}$ & $0.67 \mathrm{a}$ & 0.66 \\
\hline $\mathrm{N}_{60}$ & $1.61 \mathrm{~b}$ & $1.68 \mathrm{a}$ & $1.68 \mathrm{a}$ & $1.68 \mathrm{a}$ & 1.66 & $0.71 \mathrm{a}$ & $0.75 a$ & $0.61 \mathrm{a}$ & $0.70 \mathrm{a}$ & 0.69 \\
\hline $\mathrm{N}_{90}$ & $1.68 \mathrm{a}$ & $1.68 \mathrm{a}$ & $1.68 \mathrm{a}$ & $1.68 \mathrm{a}$ & 1.68 & $0.71 \mathrm{a}$ & $0.75 \mathrm{a}$ & $0.61 \mathrm{a}$ & $0.70 \mathrm{a}$ & 0.69 \\
\hline ean & 1.53 & 1.58 & 1.56 & 1.51 & 1.54 & 0.66 & 0.70 & 0.57 & 0.65 & 0.64 \\
\hline & & $D(0.01$ & & & & $(0.05)$ & & $\mathrm{D}(0.01$ & & \\
\hline $\begin{array}{l}\text { levels } \\
\text { arieties }\end{array}$ & $\begin{array}{c}0.070 \\
0.062\end{array}$ & & 0.0 & & & $\begin{array}{l}\text { levels } \\
\text { arieties }\end{array}$ & & $\begin{array}{l}072 \\
073\end{array}$ & & $\begin{array}{l}0.100 \\
0.099\end{array}$ \\
\hline
\end{tabular}

\section{6- Nitrogen uptake by grain and straw ( $\mathrm{kg} / \mathrm{fed}$.).}

The results of $\mathrm{N}$ uptake by grain and straw of wheat varieties presented in Table 8 which illustrated that wheat varieties differed significantly. The highest mean value of grain N uptake of Gimiza 9 (38.63 kg/fed.) followed by Giza 168 ( $36.45 \mathrm{~kg} / \mathrm{fed}$.), Sakha 61 (32.72 kg/fed.) and Sakha 93 ( $30.64 \mathrm{~kg} \mathrm{~kg} / \mathrm{fed}$.). These results were corresponded to the values of grain yield Table 2. The values of straw N uptake had the order of Gimiza 9 > Giza 168 > Sakha 93 > Sakha 61. The values of N uptake by grain and straw highly significant increased as $\mathrm{N}$ levels increased, where the mean value of $\mathrm{N}$ uptake by grain yield increased from $15.72 \mathrm{~kg} / \mathrm{fed}$. to $36.13,42.35$, and $44.23 \mathrm{~kg} / \mathrm{fed}$. as $\mathrm{N}$ levels increased from $\mathrm{N}_{0}$ to $\mathrm{N}_{30}, \mathrm{~N}_{60}$ and $\mathrm{N}_{90}$ respectively. The values of $\mathrm{N}$ uptake by straw had the same trend. The interaction values showed that the highest value of grain $\mathrm{N}$ uptake (47.41 $\mathrm{kg} / \mathrm{fed}$.) was obtained with Gimiza 9 as $\mathrm{N}_{90}$ used. The same treatment had the highest value of straw $\mathrm{N}$ uptake ( $48.88 \mathrm{~kg} / \mathrm{fed}$.).

Table 7: $\mathrm{N}$ uptake ( $\mathrm{kg} / \mathrm{fed}$.) by grain and straw as affected by varieties and $\mathrm{N}$ levels (mean of two seasons 2009/10\&2010/11).

\begin{tabular}{|c|c|c|c|c|c|c|c|c|c|c|}
\hline & \multicolumn{4}{|c|}{ Grain N uptake ( kg/fed.) } & \multicolumn{3}{c|}{ Straw N uptake ( kg/fed.) } \\
\cline { 2 - 10 } & $\begin{array}{c}\text { Gimiza } \\
9\end{array}$ & $\begin{array}{c}\text { Giza } \\
168\end{array}$ & $\begin{array}{c}\text { Sakha } \\
61\end{array}$ & $\begin{array}{c}\text { Sakha } \\
93\end{array}$ & mean & $\begin{array}{c}\text { Gimiza } \\
9\end{array}$ & $\begin{array}{c}\text { Giza } \\
168\end{array}$ & $\begin{array}{c}\text { Sakha } \\
61\end{array}$ & $\begin{array}{c}\text { Sakha } \\
93\end{array}$ & mean \\
\hline $\mathrm{N}_{0}$ & $18.77 \mathrm{~b}$ & $14.82 \mathrm{~b}$ & $15.31 \mathrm{c}$ & $14.15 \mathrm{c}$ & 15.76 & $\begin{array}{c}25.72 \mathrm{c} \\
20.71 \mathrm{c}\end{array}$ & $\begin{array}{c}20.64 \mathrm{~b} \\
19.97 \mathrm{~d}\end{array}$ & 21.76 \\
$\mathrm{~N}_{30}$ & $43.45 \mathrm{a}$ & $41.88 \mathrm{a}$ & $35.06 \mathrm{~b}$ & $24.12 \mathrm{~b}$ & 36.13 & $38.96 \mathrm{~b}$ & $39.41 \mathrm{~b}$ & $28.00 \mathrm{a}$ & $27.85 \mathrm{c}$ & 33.56 \\
$\mathrm{~N}_{60}$ & $45.06 \mathrm{a}$ & $44.05 \mathrm{a}$ & $38.91 \mathrm{a}$ & $41.40 \mathrm{a}$ & 42.35 & $45.37 \mathrm{a}$ & $43.09 \mathrm{a}$ & $30.12 \mathrm{a}$ & $33.30 \mathrm{~b}$ & 37.97 \\
$\mathrm{~N}_{90}$ & $47.41 \mathrm{a}$ & $45.04 \mathrm{a}$ & $41.58 \mathrm{a}$ & $42.87 \mathrm{a}$ & 44.23 & $48.88 \mathrm{a}$ & $44.85 \mathrm{a}$ & $29.73 \mathrm{a}$ & $38.07 \mathrm{a}$ & 40.38 \\
\hline Mean & 38.67 & 36.45 & 32.72 & 30.64 & 34.61 & 39.74 & 37.02 & 27.12 & 29.80 & 33.42 \\
\hline LD (0.05)
\end{tabular}

\section{7- Protein content (kg/fed.)}

Data in Table 9 showed protein content of wheat grain and straw as affected by varieties and $\mathrm{N}$ levels. The protein content of grain yield differed significantly in the two seasons. Gimiza 9 was the highest mean value ( 220.2 
$\mathrm{kg} / \mathrm{fed}$.) of protein content while Sakha 93 was the lowest one ( 174.6 $\mathrm{kg} / \mathrm{fed}$.). With regard to protein content of straw yield, Gimiza 9 was the highest and. Sakha 61 was the lowest. Data also showed that protein content of grain and straw was significantly increased as $\mathrm{N}$ levels increased from $\mathrm{N}_{0}$ to $N_{30}, N_{60}$ and $N_{90}$, respectively in the two seasons. It is clear from data that the highest protein content of grain and straw were obtained with Gimiza 9 and $\mathrm{N}_{90}$ level and the lowest with Sakha 93 and $\mathrm{N}_{0}$. These results were in agreement with those obtained by Gauer et al. (1992) who stated that increasing protein content by applying higher rates of $\mathrm{N}$ fertilizer. Abedi et al. ( 2011) indicated that application of $240 \mathrm{~kg} \mathrm{~N} / \mathrm{ha}$ resulted in the maximum amount of seed protein content

Table 8: Protein content ( $\mathrm{kg} / \mathrm{fed}$.) of grain and straw as affected by varieties and $\mathrm{N}$ levels (mean of two seasons 2009/10\&2010/11).

\begin{tabular}{|c|c|c|c|c|c|c|c|c|c|c|}
\hline & \multicolumn{5}{|c|}{ Grain protein content (kg/fed.) } & \multicolumn{5}{|c|}{ Straw protein content (kg/fed.) } \\
\hline & Gimia 9 & $\begin{array}{l}\text { Giza } \\
168\end{array}$ & \begin{tabular}{|c|} 
Sakha \\
61
\end{tabular} & \begin{tabular}{|c|} 
Sakha \\
93
\end{tabular} & mean & G & $\begin{array}{c}\text { Giza } \\
168\end{array}$ & \begin{tabular}{|c|} 
Sakha \\
61
\end{tabular} & $\begin{array}{c}\text { Sakha } \\
93\end{array}$ & mean \\
\hline $\mathrm{N}_{0}$ & & $84.5 \mathrm{c}$ & $87.3 \mathrm{~d}$ & $80.65 \mathrm{c}$ & & & $118.1 \mathrm{c}$ & $117.7 \mathrm{c}$ & $113.8 \mathrm{~d}$ & \\
\hline & & $238.7 \mathrm{~b}$ & 19 & 13 & & & & & & 3 \\
\hline $\mathrm{N}_{60}$ & $256.9 \mathrm{~b}$ & $251.1 \mathrm{a}$ & $221.8 \mathrm{~b}$ & $236.0 \mathrm{a}$ & 24 & $3.6 \mathrm{~b}$ & $a$ & 17 & $\mathrm{~b}$ & 4 \\
\hline $\mathrm{N}_{90}$ & $270.2 \mathrm{a}$ & $256.7 \mathrm{a}$ & $237.0 \mathrm{a}$ & $244.4 \mathrm{a}$ & & $278.6 \mathrm{a}$ & $255.6 \mathrm{a}$ & $169.5 \mathrm{a}$ & $217.0 \mathrm{a}$ & .2 \\
\hline an & 220.2 & 207.8 & 186.5 & 174.6 & 3 & 226.5 & 211.0 & 154.6 & 169.9 & 19 \\
\hline \multicolumn{6}{|c|}{ LSD (0.05) $\quad$ LSD (0.01) } & \multicolumn{3}{|c|}{ LSD (0.05) } & \multicolumn{2}{|c|}{ SD (0.01) } \\
\hline $\begin{array}{l}\mathrm{N} \text { levels } \\
\text { varieties }\end{array}$ & $\begin{array}{r}12.331 \\
10.690\end{array}$ & & 7.497 & & 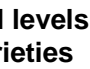 & & & $\begin{array}{l}.609 \\
0.174\end{array}$ & & \\
\hline
\end{tabular}

\section{8-The net return of wheat varieties (L.E./fed)}

The returns of different varieties used in the trials are shown in Table 6. Data showed that there were differences between the used varieties. With regard to the return of grain yield, the mean values of varieties take the following order: Gimiza $9>$ Giza $168>$ Sakha $61>$ Sakha 93. The return of straw yield had the same trend. Data of total return of grain + straw showed that Gimiza 9 had the highest mean value of 8810.0 L.E./fed. followed by Giza 168 (7922.8 L.E./fed.), Sakha 61 (7203.3 L.E./fed.) and Sakha 93 (6915.4 L.E./fed.), respectively. These results showed that Gimiza 9 was higher than Giza 168, Sakha 93 and Sakha 61 with 11.2\%, 22.3\% and 27.4\% respectively. The values of net return were at the same trend. The increase over control showed that Giza 168 had the highest mean value of 3265.35 L.E./fed. where this variety can utilized from fertilizer over than other three varieties. Results also showed that the return of grain, the return of straw, total return of grain and straw, net return of fertilizer and increase over control increased as $\mathrm{N}$ levels increased from $\mathrm{N}_{0}$ to $\mathrm{N}_{30}, \mathrm{~N}_{60}$ and $\mathrm{N}_{90}$ respectively due to the increase of yield as shown in Tables 2 and 3 . For example the return of grain yield of Gimiza 9 increased from 4066.4 L.E./fed. to 7017.4, 7277.4 and 7337.2 L.E./fed. as $N$ levels increased from $N_{0}$ to $N_{30}, N_{60}$ and $N_{90}$ respectively. The interaction values showed that the highest value of net return of 9798.7 L.E./fed. was obtained with Gimiza 9 with $\mathrm{N}_{90}$ and the lowest value of 8092.1 L.E./fed. was recorded with Sakha 61 with the same N level. Similar results were obtained by Atia et al. (2012). 
Table 9: The returns of grain and straw yields, and the net return of fertilizer as affected by wheat varieties and nitrogen levels (mean of two seasons 2009/10\&2010/11).

\begin{tabular}{|c|c|c|c|c|c|c|c|}
\hline \multicolumn{2}{|c|}{ Treatments } & \multirow{3}{*}{\begin{tabular}{|c}
$\begin{array}{c}\text { Return } \\
\text { of grain } \\
\text { yield } \\
\text { L.E /fed. }\end{array}$ \\
4066.4 \\
70174
\end{tabular}} & \multirow{2}{*}{$\begin{array}{c}\text { Return } \\
\text { of straw } \\
\text { yield } \\
\text { L.E /fed. } \\
1905.2\end{array}$} & $\begin{array}{l}\text { Gross } \\
\text { return } \\
\text { ( grain+ } \\
\text { straw) } \\
\text { yields } \\
\text { L.E /fed. }\end{array}$ & \multirow{2}{*}{$\begin{array}{c}\begin{array}{c}\text { Cost } \\
\text { Of } \\
\text { fertilizer }\end{array} \\
\text { L.E /fed. } \\
0.0\end{array}$} & \multirow{2}{*}{$\begin{array}{l}\text { Net return } \\
\text { L.E /fed. } \\
5971.6\end{array}$} & \multirow{3}{*}{$\begin{array}{c}\begin{array}{c}\text { Net return } \\
\text { of fertilizer } \\
\text { L.E /fed. }\end{array} \\
0.0 \\
3274.3\end{array}$} \\
\hline & $\mathrm{N}_{0}$ & & & 5971.6 & & & \\
\hline Gimiza 9 & $\mathrm{~N}_{30}$ & & 2326.0 & 9343.4 & 97.5 & 9245.9 & \\
\hline & $\mathrm{N}_{60}$ & 7277.4 & 2556.4 & 9833.8 & 195.0 & 9638.8 & 3667.2 \\
\hline & $\mathrm{N}_{90}$ & 7337.2 & 2754.0 & 10091.2 & 292.5 & 9798.7 & 3827.1 \\
\hline \multicolumn{2}{|c|}{ Mean } & 6424.6 & 2385.4 & 8810.0 & 146.25 & 8663.75 & 2692.15 \\
\hline \multirow[t]{4}{*}{ Giza 168} & $\mathrm{~N}_{0}$ & 3057.6 & 1453.6 & 4511.2 & 0.0 & 4511.2 & 0.0 \\
\hline & $\mathrm{N}_{30}$ & 6481.8 & 2220.4 & 8702.2 & 97.5 & 8604.7 & 4093.5 \\
\hline & $\mathrm{N}_{60}$ & 6817.2 & 2298.0 & 9115.2 & 195.0 & 8920.2 & 4409.0 \\
\hline & $\mathrm{N}_{90}$ & 6970.6 & 2392.0 & 9362.6 & 292.5 & 9070.1 & 4558.9 \\
\hline \multicolumn{2}{|c|}{ Mean } & 5831.8 & 2091 & 7922.8 & 146.25 & 7776.55 & 3265.35 \\
\hline \multirow[t]{4}{*}{ Sakha 61} & $\mathrm{~N}_{0}$ & 3317.6 & 1756.8 & 5074.4 & 0.0 & 5074.4 & 0.0 \\
\hline & $\mathrm{N}_{30}$ & 5426.2 & 1930.8 & 7357.0 & 97.5 & 7259.5 & 2185.1 \\
\hline & $\mathrm{N}_{60}$ & 6021.6 & 1975.6 & 7997.2 & 195.0 & 7802.2 & 2727.8 \\
\hline & $\mathrm{N}_{90}$ & 6435.0 & 1949.6 & 8384.6 & 292.5 & 8092.1 & 3017.7 \\
\hline \multicolumn{2}{|c|}{ Mean } & 5300.1 & 1903.2 & 7203.3 & 146.25 & 7057.05 & 1982.65 \\
\hline \multirow[t]{4}{*}{ Sakha 93} & $\mathrm{~N}_{0}$ & 2919.8 & 1479.2 & 4399.0 & 0.0 & 4399.0 & 0.0 \\
\hline & $\mathrm{N}_{30}$ & 4479.8 & 1662.8 & 6142.6 & 97.5 & 6045.1 & 1646.1 \\
\hline & $\mathrm{N}_{60}$ & 6406.4 & 1902.8 & 8309.2 & 195.0 & 8114.2 & 3715.2 \\
\hline & $\mathrm{N}_{90}$ & 6635.2 & 2175.6 & 8810.8 & 292.5 & 8518.3 & 4119.3 \\
\hline \multicolumn{2}{|c|}{ Mean } & 5110.3 & 1805.1 & 6915.4 & 146.25 & 6769.15 & 2370.15 \\
\hline
\end{tabular}

The mean price of wheat grain at the two seasons 2009/2010 = 2.6 L.E./kg

The mean price of wheat straw at the two seasons $2009 / 2010=0.4$ L.E. $/ \mathrm{kg}$

Price of urea fertilizer unit ( $1 \mathrm{~kg} \mathrm{~N})=3.25 \mathrm{L.E}$.

\section{REFERENCES}

Abd Allah-Soheir M. H. and A.A. El-Gammaal (2009). Estimate of heterosis and cmbining ability in diallel bread wheat crosses (Triticum aestivum L.). Alex. Sci. Exch. J., 30(1): 76-85.

Abdelgadir, E.M.; E.M. Fadul; E.A. Fageer and E.A. Ali, (2010). Response of wheat to nitrogen fertilizer at reclaimed high terrace salt affected soils in Sudan. J. Agric. Soc. Sci., 6: 43-47

Abedi, T.; A. Alemzadeh and S. A. Kazemeini (2011). Wheat yield and grain protein response to nitrogen amount and timing. Aust., J. Crop Sci. 5(3):330-336.

Atia, R. H. (2005). A quantitative evaluation of soybean response to nitrogen under sulphur and phosphorus addition. Alex. Sci. Exch. J., 26(4): 355-362.

Atia, R. H., H. S. Hamoud and A. S. M. El-Saady (2009). Effect of (Halex-2) biofertilizer inoculation on cowpea yield and mineral fertilization- $\mathrm{N}$ optimization. J. Agric. Sci. Mansoura Univ. 34: 5487- 5494.

Atia, R.H. .; M. A. Metwally and Gh.Sh. Al-Atawy (2012). Effect of irrigation water amounts and nitrogen rates on optimum maize yield and net 
return under drip irrigation system at Northwest Delta, Egypt. . J. Sol Sci. and Agric. Eng. Mansoura Univ., 3(5): 549-559.

Atta Allah, S.A. and G.A. Mohammed (2003). Response of wheat grown in newly reclaimed soil to poultry manure and nitrogen fertilization. J. Agric. Sci., Mansoura Univ., 28(10: 7531-7538.

Black, C.A.; D.D. Evans; J.L. White, L.E. Ensuminger and F.F. Clark (1965). Methods of Soil Analysis. Am. Soc. Agron. Inc. Publ. Madison, Wisconsin.

Cochran, W.G. and G.M. Cox (1957). Experimental Designs. 2nd Ed. pp. 611, John Wiley and Sons, Inc. New York.

Daniel C, and E. Triboi (2000) Effects of temperature and nitrogen nutrition on the grain composition of winter wheat: effects on gliadin content and composition. J. Cereal Sci 32: 45-56.

Duncan, D.B. (1955). Multiple Range and Multiple F-Test Biometrics. 11:1-42.

El-Zaher, H. and M. A. Salem (2005). The Quantitative response of wheat yield to

$\mathrm{N}$-fertilizer in calcareous soil. Alex. Sci. Exch. J., 26(3): 265-274..

Gauer, L. E.; A. C. Grant; D. T. Gehl, and L. D. Bailey (1992). Effects of nitrogen fertilization on grain protein content, nitrogen uptake, and nitrogen use efficiency of six spring wheat (Triticum aestivum L.) cultivars, in relation to estimated moisture supply. Can. J. Plant Sci. $72: 235241$

Hadzic, A. (1986). The effect of different rates of nitrogen on the yield of spring wheat varieties. Radovi-Poljoprivrednog-fakulteta-Univerziteta-uSarajevu (Yugoslavia) 34: 5-14

Hassanein, M. A. and G. M. El-Shebiny (2000). Contribution of bio- and mineral nitrogen fertilization in sugar beet yield. Alex. Sci. Exch., 21(2): 129-143.

Jackson, M.L. (1967). Soil Chemical Analysis. Prentice Hall of India Private Limited, New Delhi.

Knany, R.E.; A.S.M. El-Saady and R.H. Atia, (2011). Some wheat varieties response to nitrogen fertilization levels and its effect on N-uptake. J. of Soil Sci. and Agric. Eng. Mansoura Univ., 2(5):585-596.

Mansour, A.A. and A.H. Bassiouny (2009). Seeding and nitrogen rates required to maximize yield of Gemmiza 9 wheat cultivar in Eastern Delta region. J. Agric. Sci. Mansoura Univ., 34(5): 4991-5002.

Mashali, S.; A. Balba E. Alwakil; R.H. Atia and A. Abou Elkhir (2011). Quantitative relations of added $\mathrm{N}$ fertilizer and soil-N for wheat plants irrigated with different saline water in Egypt. In: Böden verstehen Böden nutzen -Bödun fit machen, 3.- 9.September, Berlin.

Mattas, K. K., R. S. Uppal and R. P. Singh (2011). Effect of varieties and nitrogen management on the growth yield and nitrogen uptake of durum wheat. Res. J. Agric. Sci., 2(2): 376-380

Mowafy, S.A.E. (2008). Effect of organic manure and fertilization levels on floral fertility, inter and intra spikelets competition and grain yield potentiality of three bread wheat cultivars under sandy soil conditions. Zagazig J. Agric. Res. 33(5): 1015-1052. 
Salem, M.A. (2005). Effect of nitrogen rates and yield components of bread wheat (Triticum aestivum, L.) genotypes under newly reclaimed land conditions. J. Agric. Sci. Mansoura Univ., 30(11): 6481-6490.

Semenov, M.A., P.D. Jamieson, and P. Martre. (2007). Deconvoluting nitrogen use efficiency in wheat: A simulation study. Eur. J. Agron. 26:283-294.

Tammam, A.M. and M.B. Tawfils (2004). Effect of sowing dates and nitrogen fertilizer levels in relation to yield and yield components of durum wheat under Upper Egypt environments. J. Agric. Sci. Mansoura Univ., 29(10): 5431-5442.

Thabet A. G. and A. M. Balba (1994). Soil and fertilizer-N efficiencies using wheat grain response equations to $\mathrm{N}$ and tillage. Arid Soil Research and Rehabilitation. 8: 115-124.

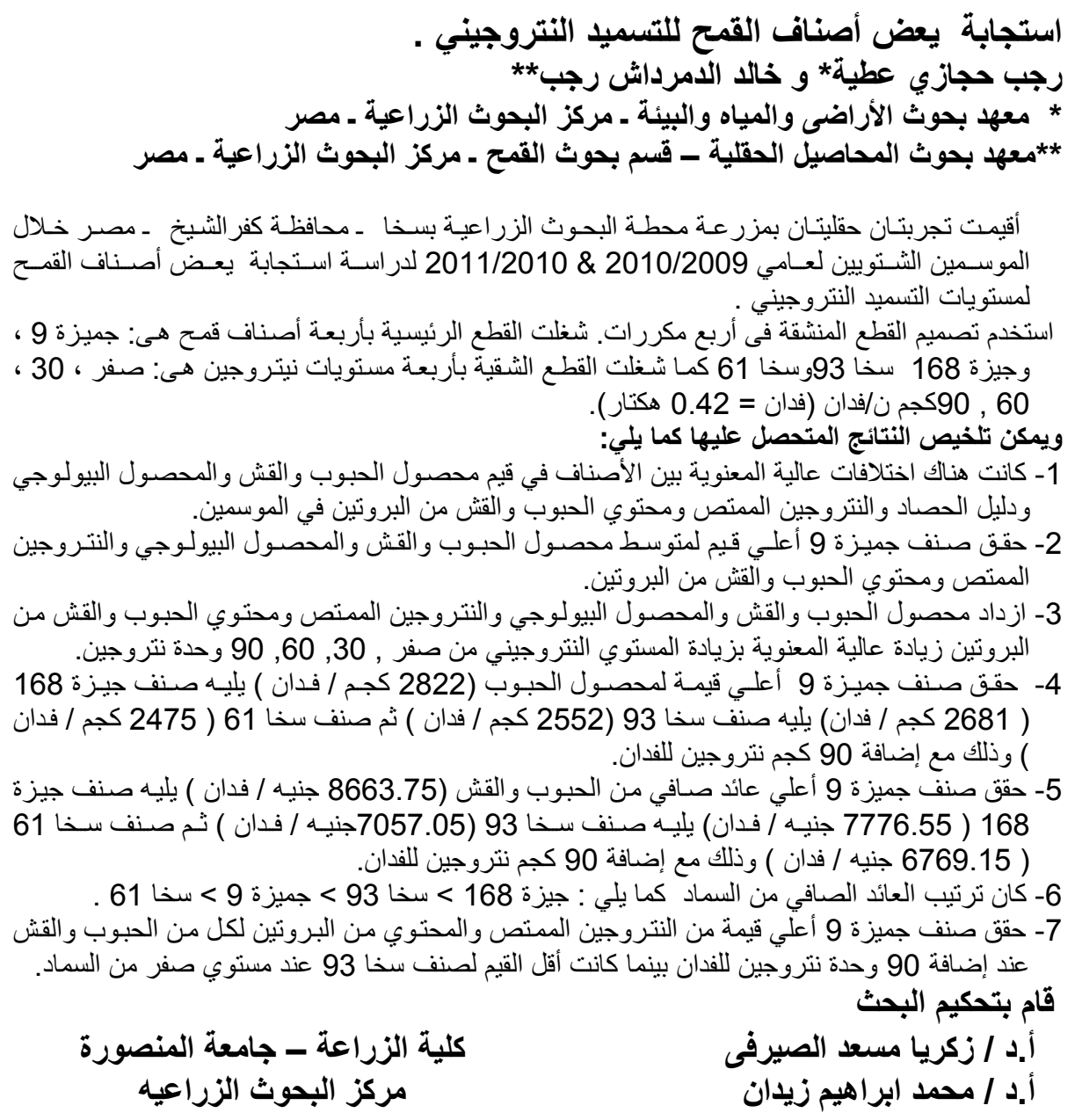

